\title{
Strategic Influence of Technological Innovations on Financial Performance of Commercial Banks in Kenya Nakuru Town, Kenya
}

\author{
Mbogori, Lucy Muthoni ${ }^{1}$,Wanyoike D.M ${ }^{2}$ \\ (MBA Student, Jomo Kenyatta University of Agriculture and Technology, Kenya) \\ (Lecturer, Jomo Kenyatta University of Agriculture and Technology, Kenya.)
}

\begin{abstract}
The dynamic nature of global business environment which results from technological advancements, economic restructuring, labor movements, and public demands for better products and services have forced organizations to reconsider their business strategies in order to achieve a sustained competitive advantage. The ability to innovate therefore is increasingly viewed as an important factor in developing and sustaining competitive advantage. However the relationship between the growing investment in technology based bank technological innovations and bank financial performance in Kenya needs to be studied. This study sought to fill the existing research gap by conducting a study on how the technological innovations have contributed to the financial performance of commercial banks in Kenya. Specifically, the study was guided by four independent variables; internet banking, mobile banking, agency banking and credit reference bureau. The dependent variable for the study was financial performance of commercial banks. The study was carried out in commercial banks in Nakuru town sub-county, Kenya. Descriptive research design was used, but a cross-sectional research survey method was applied. The target population comprised of 58 managers drawn from the 29 banks hence a census was conducted. Structured questionnaires were used to collect primary data from the respondents. Prior to the main study, the research instrument was pilot tested in order to determine both its reliability and validity. The reliability of the instrument was tested using the Cronbach's alpha ( $\alpha$ ) where $\alpha \geq 0.7$ was accepted. On the other hand, content validity of the instrument was determined by seeking expert opinion of the University supervisors. The Statistical Package for Social Sciences version 20 software was used to process and analyze the data collected. Data analysis was in form of descriptive and inferential statistics. Study findings were presented in form of tables that reflected summary statistics. The study findings showed that internet banking, mobile banking, agency banking and the credit reference bureau have a positive $(r>0)$ influence on the financial performance of the commercial banks thus the four study hypothesis were rejected. The study recommends that the commercial banks should improve the internet banking systems to serve their customers more effectively without delays occasioned by system failure, commercial banks keep adopting and using mobile banking in their operations because the number of people with access to mobile hand set is increasing every day, financial institutions should continue offering low transaction rates within their local agency points. CRB should continue furnishing commercial banks with relevant information on the credit worthiness of borrowers to help eliminate bad and non-performing loans which will see the banks lower the insurances levy there by encouraging more people to borrow and thus improve financial performance of the banks. Keywords: Strategic influence, internet banking, mobile banking, agency banking, commercial bank.
\end{abstract}

\section{Introduction}

According to Vasya and Patrick (2006) recent development of information technology has led to major changes in the way services are delivered to the customers. Nowadays, customers are using more and more selfservice options, which are more convenient and fast. Kumar (2014) suggests that customers' growing use of digital channels for banking and their demand for an individualized experience have forced many banks to revisit their customer service efforts. In the face of increasing competition from emerging digital banks, which are redefining customer satisfaction and luring younger customers, traditional banks must leverage digital channels to create a more rewarding customer satisfaction.

\section{Statement of the Problem}

Current and future challenges and opportunities facing business organizations are in the fields of sustainable development; e-Commerce; and new product development. The power of the technological innovation capability construct is that it is generally realizable to all these domains, as it relates to the organizational potential to convert new ideas into commercial and community value.

Incremental technological innovation produces small continuous changes and is often visible in organizations in the form of continuous improvement.

Banks consider that the cumulative gains in efficiency are much greater overtime than those, 
which come from occasional radical change. However, many of these short-and medium term gains are quickly eroded and absorbed into the industry standard and therefore cannot be depended upon as a prerequisite for survival and growth. The banking industry in Kenya has undergone phenomenal growth over the last decade. Over the last five years, the banking sector has witnessed a continued upsurge in financial innovations.

This can be attributed to the introduction of Value capping, agent banking model, internet banking, Cheque Truncation System (CTS), mobile banking and the establishment of a credit reference bureau. The relationship between the growing investment in technology based bank technological innovations and bank financial performance in Kenya needs to be studied. There is need therefore to establish whether technological innovations have contributed to the financial performance of commercial banks in Kenya. This study sought to establish whether the heavy investment or more advancement of commercial banks with regards to technology translates to higher performance.

\section{Objectives}

i. To establish how internet banking strategically influences the financial performance of commercial banks in Kenya

ii. To To find out how mobile banking strategically influences the financial performance of commercial banks in Kenya

iii. To establish how agency banking strategically influences the financial performance of commercial banks in Kenya.

\section{Review Of Literature}

Internet banking refers to the use of the internet as a delivery channel for banking services, which includes all traditional services such as balance enquiry, printing statement, fund transfer to other accounts, bills payment and new banking services such as electronic bill presentment and payment (Frust, Lang, \&Nolle, 2000) without visiting a bank (Mukherjee \&Nath, 2003). Dube et al (2009) defined internet banking as the systems that enable bank customers to get access to their accounts and general information on bank products and services through the use of the bank's website, without the intervention or inconvenience of sending letters, faxes, original signatures and telephone confirmations. With the exception of cash withdrawals, internet banking gives customers access to almost any type of banking transaction at the click of a mouse (Padachi et al, 2008). Bradley and Stewart (2003) added on to this definition by saying that internet banking provides universal connection from any location worldwide and is universally accessible from any internet linked computer.

The term mobile banking is used to denote the access to banking services and facilities offered by a financial institution such as account based savings, payment transactions and other products by use of an electronic mobile device. Mobile banking has yielded a multiple effect on the number of solutions available to clients. This is in addition to more efficient transactional environment and the high substitution of banking points (Ongwenyi, 2012). Porteous, (2006) distinguishes two aspects of mobile banking; Additive and transformational characteristics. Additive aspects are those in which a mobile phone is merely another channel to an existing mobile phone. Mobile banking is additive when it merely adds to the range of choices or enhances the conveniences of existing customers of mainstream financial institutions. Transformational characteristics arise when the financial product linked to the use of mobile phone is targeted to individuals who do not hold formal bank accounts with the conventional banking institutions.

Agency banking refers to contracting of a retail or postal outlet by a financial institution or a mobile network operator to process bank clients' transactions. It is different from a branch teller, since it is the owner or an employee of the retail outlet who conducts the transactions, ranging from: deposits, withdrawals, funds transfers, bill payments, account balance inquiry, receiving government benefits or direct deposits from employers. Banking agents may include: pharmacies, supermarkets, convenience stores, lottery outlets and post offices (CGAP, 2006). The trend of agent banking is evident in many nations all over the globe, such as in Australia where post offices are used as bank agents, France utilizing corner stores, Brazil making use of lottery outlets to provide financial services, Kenya pioneering the mobile financial services, Nigeria, South Africa and the Philippines (Siedek, 2008).

\section{Conceptual Framework}

The study was structured based on the conceptual framework shown below. 


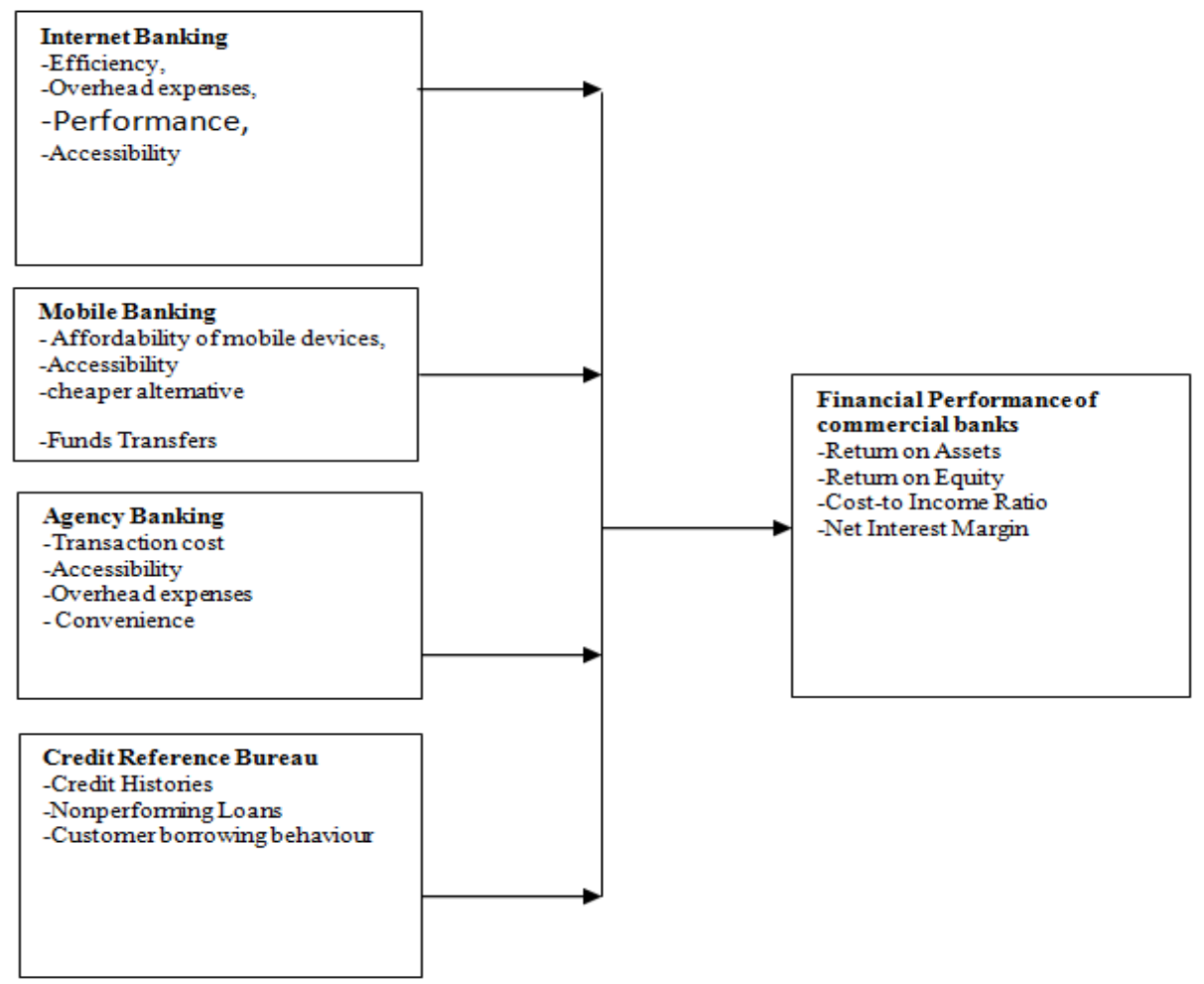

\section{Research Design}

\section{Methodology}

Kothari (2004) argues that research design is the conceptual structure within which research is conducted; it constitutes the blueprint for the collection, measurement and analysis of data. The study used the descriptive survey design. Both quantitative and qualitative techniques will be used. The study sought to obtain information from the branch managers, and credit managers of the banks in Nakuru town Sub-county.

\section{Study Population}

Population is asserted to be an aggregate of all the members that conform to certain criteria (Polit\&Hungler, 1999). The target population is simply the collection of elements (or respondents) that possess the data being sought by the researcher (Orodho, 2005). It is the population to which the findings of the study are generalized. The target population comprises of the commercial banks in Kenya. The accessible population comprises of commercial banks in Nakuru town Sub-county. There are 29 banks in Nakuru town sub-county according to data obtained from the central bank. In this study, the respondents were the branch manager and credit manager in the aforementioned commercial banks giving a total of 58 respondents, hence a census survey was conducted.

\section{Research Instrument}

The study adopted structured questionnaire for primary data. The questionnaire captured the demographic information of the respondents. More importantly it contained statements and/or questions relative to both independent and dependent variables. The questionnaire was structured in conformity with Likert scale (5-strongly agree, 4-agree, 3-neutral, 2-disagree and 1-strongly disagree). Likert scale is appropriate since the data collected will enable proper analysis in terms of variability and central tendencies (Singh \& Smith, 2006).

\section{Data Processing and Analysis}

The collected data was coded and the data file structured using the Statistical Package for Social Sciences (SPSS) software version 20. The coding was in line with the types (independent and dependent) and values of the variables. The missing values in terms of non-responses were screened. Screening facilitates the cleaning of data in order to minimize the outliers which can otherwise compromise the study findings. The study sought to find the descriptive statistics in form of mean and standard deviation. The relationship between variables (independent and dependent) was explored using the inferential statistics (Pearson's correlation coefficient). The aim of the correlation analysis was not only to establish whether there exists a 
relationship between variables, but also the magnitude and direction of the relationship.

The regression model adopted in tandem with the study variables is as shown:

$Y=\beta_{0}+\beta_{1} X_{1}+\beta_{2} X_{2}+\beta_{3} X_{3}+\beta_{4} X_{4}+\mu$

Where;

Y represents the performance (dependent variable);

$\beta_{0}$ represents the Y intercept;

$\beta_{1}-\beta_{4}$ represents the coefficients of the variables;

$\mathrm{X}_{1}$ represents internet banking,

$\mathrm{X}_{2}$ mobile banking,

$\mathrm{X}_{3}$ agency banking,

$\mathrm{X}_{4}$ credit reference bureau listing and

$\mu$ is the error term.

The study findings will be presented in form of tables depicting frequencies, descriptive statistics and inferential statistics.

\section{Inferential Statistics}

\section{Findings}

In order to be able to draw pertinent conclusions, the data collected was inferentially analyzed using the Pearson's correlation coefficient. This was supported by the fact that the data was on a Likert scale. As such the composite scores (means) for each independent variable was correlated against the composite scores for dependent variable (Boone \& Boone, 2012).

Table 1: Relationship between Internet Banking and Financial Performance of Commercial Banks

\begin{tabular}{|l|l|l|}
\hline \multirow{3}{*}{ Internet Banking } & & Financial Performance of Commercial Banks \\
\cline { 2 - 3 } & Pearson Correlation & $.752^{* *}$ \\
\cline { 2 - 3 } & Sig. (2-tailed) & .000 \\
\cline { 2 - 3 } & $\mathrm{n}$ & 55 \\
\hline
\end{tabular}

The study sought to find the effect of Internet Banking on Financial Performance of Commercial Banks. It was established that there is a strong positive correlation between Internet Banking and Financial Performance of Commercial Banks $(r=0.752 ; \mathrm{p}<0.01)$. This means that internet banking has a strong and positive effect on financial performance of commercial banks. When the usage of internet banking increases, the financial performance of the commercial banks improves. Furst et al (2000), found that banks in all sizes and categories offering internet banking were generally more profitable and tended to rely less heavily on traditional banking activities. Therefore, the first hypothesis $\left(\mathbf{H}_{01}\right.$ : internet banking has no significant influence on the environment management practices adopted by manufacturing companies) was rejected.

Table 2: Relationship between Mobile Banking and Financial Performance of Commercial Banks

\begin{tabular}{|l|l|l|l|}
\hline & & Financial Performance of Commercial Banks \\
\hline \multirow{3}{*}{ Mobile Banking } & Pearson Correlation & $.579^{* *}$ & \\
\cline { 2 - 4 } & Sig. (2-tailed) & .000 & 55 \\
\cline { 2 - 3 } & $\mathrm{n}$ & 55 \\
\hline
\end{tabular}

The findings showed that there exists a positive strong relationship between mobile banking and financial performance of commercial banks $(r=0.579 ; \mathrm{p}<0.05)$. This was interpreted to imply that mobile banking had significant effect on financial performance of commercial banks. It further meant that the more the usage of mobile banking, the more the financial performance of commercial banks improves. The findings led to the rejection of the second hypothesis $\left(\mathbf{H}_{\mathbf{0 2}}\right)$ which stated that mobile banking has no significant effect on the financial performance of commercial banks.

Table 3: Relationship Between Agency Banking and Financial Performance of Commercial Banks

\begin{tabular}{|l|l|l|}
\hline & & Financial Performance of Commercial Banks \\
\hline \multirow{2}{*}{ Agency Banking } & Pearson Correlation & $.753^{* *}$ \\
\cline { 2 - 3 } & Sig. (2-tailed) & .000 \\
\cline { 2 - 3 } & $\mathrm{n}$ & 55 \\
\hline
\end{tabular}

Agency Banking was found to strongly, positively and significantly affect the financial performance of commercial banks. The findings of the correlation analysis were $(r=0.753 ; p<0.01)$. This implied that Agency Banking is very crucial to financial performance of commercial banks. Conclusively, the third hypothesis $\left(\mathbf{H}_{\mathbf{0 3}}\right.$ : Agency Banking does not significantly affect the Financial Performance of Commercial Banks) was also rejected. 


\section{Regression Analysis}

In this study, a multiple regression analysis was conducted to test the relationship among predictor variables. The research used statistical package for social sciences (SPSS V 20) to code, enter and compute the measurements of the multiple regressions.

Table 4: Model summary

\begin{tabular}{|l|l|l|l|}
\hline Model & R Squared & Adjusted R squared & Standard Err of Estimate \\
\hline 1 & 0.830666 & 0.491997 & 0.169110 \\
\hline
\end{tabular}

The adjusted $\mathrm{R}$ squared as seen in table 4 above is 0.491997 . This can be interpreted to me an $49.1 \%$ of the financial performance of the commercial banks in Kenya could be attributed to the combined effect of the predictor variables under study.

\section{Conclusions}

The study concluded that automated Internet Banking has a significant effect on Financial Performance of Commercial Banks. This is supported by a positive correlation coefficient between the two. Descriptive statistics also showed that it the respondents agreed that by offering Internet banking services, banks enhances their efficiency; and also agree that competition has contributed to intense investment in internet banking; innovation brings competition among banks more so in internet banking, internet banking services enhances our competitive advantage, internet banking services ensures there are lower overhead expenses like staff costs, Internet as a delivery channel enhances banks profitability. The respondents had highly varying responses on the statement that innovation brings competition among banks more so in internet banking with majority being neutral on the issue. This could have been brought about by the fact that some banks see internet banking as just another means of service delivery and not a source of competition.

The study also concluded that there is a significant relationship between mobile banking and financial performance of commercial banks. Results from the descriptive analysis also showed that mobile banking ensures long term customer relationship, enhances employment of advanced selling strategies. Investment in mobile banking as a strategic technological innovation has increased revenues for the banks, and so banks should continue investment in mobile banking. Mobile banking reduces cost by taking small-value transactions out of the banking hall thus improving performance of the bank. The bank is able to operate with lean staff since small value transactions are taken care of via the mobile. Financial institutions see mobile financial services as a form of branchless banking which lowers the cost involved in serving customers since the customers can carry out most transactions on their phones at the comfort of their houses. Mobile banking makes banking accessible anywhere anytime and has been contributed greatly by affordability of mobile devices.

The study also concluded that there is a significant relationship between the agency banking and financial performance of commercial banks. Analysis of the descriptive statistics also showed that the respondents indicated that agency banking has contributed to banks geographical expansion and it contributes significantly to overall banks profitability. Through agency banking, the bank reduces overhead expenses like staff costs since the agents are not bank employees and the premises they use is not owned by the banks. Agency banking is a major source of non-funded income for the banks since they don't have to put in any funds to run the agencies. Banks are encouraged to share infrastructure since at times agents hold more than one bank POS machines and hence gains economies of scale. The use of the agent banking model by banks has contributed to improved access to banking services since even clients in remote areas or in small towns which can not economically support a branch are able to access banking services.

Finally the study also concluded that there is a significant relationship between the Credit Reference Bureau and financial performance of commercial banks. The findings showed that the Credit Reference Bureau listing is a strategic control measure that increases financial performance in banks by reducing the bad loans. The bank considers information from Credit Reference Bureau while making a lending decision hence enables lenders to make an informed decision before committing to lend. Credit bureaus give credit histories of borrowers enabling lenders to reduce financial risks. Credit Reference Bureaus report is not the only determinant of lending decision according to majority of the respondents; there are other factors that are considered while making the lending decision. Being listed with Credit Reference Bureau does not mean one is not creditworthy since the bureaus list everyone with debts but grade the performing and the non performing loans.

\section{Recommendations}

Based on the conclusion, the study recommends that the commercial banks should improve the internet banking systems to serve their customers more effectively without delays occasioned by system failure.

It also recommends that commercial banks in Kenya should minimize mobile banking costs so as to encourage more customers to use the same there by improving the financial performance. 
The study further recommends that commercial banks keep adopting and using mobile banking in their operations because the number of people with access to mobile hand set is increasing every day. In addition, the convergence of mobile phones and commercial banks has revolutionized the banking operations.

The study recommends that the financial institutions should continue offering low transaction rates within their local agency points. This will lure customers to adopt this as a culture thus ensuring the future sustainability of the agency banking system. The study also recommends that the banking institutions should consider intensifying the agency banking network which will ensure services accessibility by customers and thus improving financial performance.

The study also recommends that $\mathrm{CRB}$ should continue furnishing commercial banks with relevant information on the credit worthiness of borrowers to help eliminate bad and nonperforming loans. This will see the banks lower the interest rates there by encouraging more people to borrow and thus improve financial performance.

\section{Acknowledgements}

Much thanks to God Almighty. Special thanks go to Jomo Kenyatta University of Agriculture and Technology management Nakuru campus and my ardent supervisor, Dr. Daniel M. Wanyoike for his assistance and guidance. I also thank my family for their support; my husband and my sons; and my parents and my siblings.

\section{References}

[1] Vasya, K. \&Patrik J. (2006).Quality Online Banking Services. Bachelors, Thesis, Jönköping University

[2] Kumar, V. M. (2014). Retail banking: Delivering a Meaningful Digital Customer. Experience.Meaningful-Digital-CustomerExperience-codex1036.[Accessed on 26/11/2014].

[3] Furst, K., Lang, W. \&Nolle, D. E. (2000). Who offers Internet Banking? Quarterly Journal, Office of the Comptroller of the Currency, 27-46

[4] Mukherjee, A., \&Nath, P. (2003).A model trust in online relationship banking.International Journal of Bank Marketing, 21(1), 5-15.

[5] Dube T., Chitura T., \& Runyowa, L. (2009). Adoption and use of internet Banking in Zimbabwe: An Exploratory Study, Journal of Internet Banking and Commerce, Vol 14, No1, pp 1-13

[6] Padachi K., Rojid S., Seetanah B., (2008), Investigating into the factors that influence the adoption of internet banking in Mauritius, Journal of Internet Business, Vol 5 pp99-116.

[7] Bradley, L.,\& Stewart, K. (2003). A Delphi Study of the drivers and inhibitors of Internetbanking, International Journal of Bank marketing Vol.20 (6), pp 250-260

[8] CGAP (2006). Debating The Regulation Of Branchless Banking: Agents At The Center. March 8, 2010 Retrieved On June 21.

[9] Kothari, C. R (2004). Research methodology, Methods and Techniques.New Delhi: International P Limited.

[10] Boone, H. N., Boone, D.A. (2012) Analyzing Likert Data, Journal of Extension, 50 (2). 